\title{
Análise do perfil das licitações sustentáveis realizadas por organizações militares do exército brasileiro
}

\author{
Analysis of the profile of sustainable procurements conducted by military organizations of the brazilian army
}

\author{
Alexandre de Oliveira Pereira', Ana Júlia Teixeira Senna², Ricardo Ribeiro Alves ${ }^{3}$, Cibele Rosa Gracioli
}

'Discente do curso de Bacharelado em Gestão Ambiental -Universidade Federal do Pampa (UNIPAMPA), Campus São Gabriel, RS, Brasil

2:3;4 Doutora da Universidade Federal do Pampa (UNIPAMPA), Campus São Gabriel, RS, Brasil

\section{Resumo}

A responsabilidade sobre a preservação do meio ambiente é hoje um dos principais temas balizadores das ações governamentais e não governamentais. Atualmente, o poder público começou a inserir a questão ambiental em suas políticas públicas, em especial, na aquisição de produtos e contratações de serviços. Em função da importância da dimensão ambiental na sociedade contemporânea e da relevância da temática sobre compras e licitações sustentáveis, esse trabalho teve como objetivo analisar as licitações sustentáveis realizadas pelas organizações militares do Exército brasileiro e verificar os critérios ambientais aplicados nas compras públicas por estas instituições. Para tanto, este trabalho está estruturado da seguinte forma: primeiramente, foi feito uma revisão bibliográfica sobre licitações públicas, compras governamentais e licitações sustentáveis. Posteriormente foram coletados dados secundários oriundos de fontes governamentais. Foram analisadas licitações executadas pelas organizações militares do Exército brasileiro que continham algum critério ambiental disponibilizados no site "Comprasnet", portal de compras do governo federal, a fim de diagnosticar as características das licitações sustentáveis realizadas pelas instituições. Os dados analisados evidenciaram que as licitações sustentáveis foram pouco representativas nas aquisições executadas pelo Exército. Além disso, constatou-se que há pouca variedade de itens licitados. A característica ambiental mais cobrada nas licitações foi de itens oriundos de matéria prima reciclada. Observou-se que as exigências ambientais solicitadas nos certames licitatórios foram pouco exigentes, sinalizando que as compras públicas sustentáveis deverão ser implementadas de forma gradual na economia nacional.

Palavras-chave:: Meio Ambiente; Compras Governamentais; Licitação Sustentável.

\begin{abstract}
Responsibility for environment preservation is now a major determining theme of government and non-government actions. Nowadays, the government has started inserting the environmental question in its public policies, especially, in the acquisition of products and in hiring services. By virtue of the importance of the environmental dimension in contemporary society and the relevance of the theme over purchases and sustainable procurements, the objective of this paper consisted in analyzing the sustainable procurements conducted by military organizations of the Brazilian Army and verify the environmental criteria used in the public purchases by these institutions. To this end, this paper is structured in the following way; primarily, a bibliographic revision was conducted on public bids, government purchases and sustainable procurements. Later on, secondary data were collected from government sources. Analyses included procurements conducted by military organizations of the Brazilian Army containing environmental criteria available at site "Comprasnet", purchasing portal of the federal government, with the aim to diagnose the characteristics of sustainable procurements carried out by the institutions. Analyzed data attested to the fact that sustainable procurements were barely represented in the acquisitions performed by the Army. Furthermore, it was ascertained that there was little variety of bid items. The most demanded environmental characteristic at the biddings was related to items made from recycled raw material. It was observed that the environmental requirements demanded at the bidding contests were not much exacting, signaling that public sustainable purchases should be implemented gradually in our national economy.
\end{abstract}

Keywords:Environment; Government Purchases; Sustainable Procurements. 


\section{INTRODUÇÃO}

A problemática ambiental, atualmente, apresenta um cenário de crise social e ambiental. A partir do século XX, ocorreram mudanças significativas em todas as dimensões da sociedade. O desenvolvimento de tecnologias, o aumento da expectativa de vida humana e as mudanças no estilo de vida da população mundial, demandaram um aumento considerável no consumo de matéria-prima e energia para sustentar as necessidades da sociedade (BELLEN, 2005).

Entretanto, segundo dados da Global Footprint Network (2011), a população mundial consome aproximadamente $50 \%$ dos recursos naturais que o planeta pode naturalmente repor, trazendo uma demanda excessiva sobre os recursos naturais, acarretando em passivos ambientais em níveis local, regional e global.

A partir da década de 1960, questões como aquecimento global, escassez das fontes de energia não renováveis e mudanças climáticas começaram a ser discutidas pelos líderes mundiais (SCOTTO et al., 2010).

No Brasil, o Código Florestal, publicado em 1965, (Lei no 4.771, de 15 de setembro de 1965 revogada pela Lei 12.651 de 12 de maio de 2012) (BRASIL, 1965; BRASIL, 2012), somado a Lei ${ }^{\circ}$ 6.938, de 31 de agosto em 1981 (BRASIL, 1981), que criou a Política Nacional do Meio Ambiente, foram legislações federais pioneiras que versaram sobre a proteção ao meio ambiente. Em 1988, a Constituição Federal estabeleceu que o Estado deveria garantir proteção ao meio ambiente, assegurando qualidade de vida para as gerações presentes e futuras (BRASIL, 1988).

Em termos mundiais, em 1992, ocorreu um evento primordial para as discussões sobre os problemas climáticos, na Conferência das Organizações Unidas sobre Meio Ambiente e Desenvolvimento (Unced), também conhecida como Rio 92. Neste evento, entre as propostas debatidas e metas de ações sobre a interação do ser humano com o meio ambiente, destacou-se a elaboração de um documento chamado de Agenda 21. Este documento ressaltou a importância do envolvimento de todos os níveis dos governos e atores sociais importantes, integrando objetivos econômicos, sociais e ambientais na busca de um desenvolvimento sustentável. Esse documento também mencionava a necessidade de se desenvolver uma economia verde pelas Nações (BINDERMAN et al., 2008).

Em 1999, foi sancionada a Lei n $^{\circ} 9.795$, de 27 de abril de 1999 (BRASIL, 1999), que dispõe sobre a Política Nacional de Educação Ambiental que continha, a Agenda Ambiental na Administração Pública (A3P), que consiste num programa que busca incorporar os princípios da responsabilidade socioambiental nas atividades da Administração Pública (BRASIL, 2009). Já em 2002, na Cúpula Mundial sobre Desenvolvimento Sustentável (Rio +10), em Johanesburgo, o tema "compras verdes" foi divulgado no cenário internacional, onde as autoridades públicas foram estimuladas a promover políticas de contratação públicas que considerassem a questão socioambiental (BRASIL, 2013a).

A responsabilidade sobre a preservação do meio ambiente é hoje um dos principais temas balizadores das ações governamentais e não governamentais. Atualmente, o poder público começou a inserir a questão ambiental em suas políticas públicas, em especial, na aquisição de produtos e contratações de serviços.

A lei n ${ }^{\circ} 8.666$, a Lei de Licitações, de 21 de junho de 1993 (BRASIL, 1993), no seu art. $3^{\circ}$ relata que a licitação, além de observar o princípio constitucional da isonomia, a seleção da proposta mais vantajosa para a administração deve também promover o desenvolvimento sustentável nacional em suas contratações públicas.

Para regular as licitações sustentáveis, em 19 de janeiro de, foi criada a Instrução Normativa $\mathrm{n}^{\circ} 01$ emitida pelo Ministério do Planejamento, Orçamento e Gestão - MPOG (BRASIL, 2010a), que dispõe sobre os critérios de sustentabilidade ambiental na execução dos processos licitatórios.

Em função da importância da dimensão ambiental na sociedade contemporânea e da relevância da temática sobre compras e licitações sustentáveis, esse trabalho teve como objetivo analisar o perfil das licitações sustentáveis praticados pelas organizações militares do Exército brasileiro e verificar a aplicabilidade dos conceitos ambientais na execução dos processos licitatórios por este órgão pertencente à administração pública.

Para tanto, este trabalho está estruturado da seguinte forma: primeiramente, foi feito uma revisão bibliográfica sobre licitações públicas, compras governamentais e licitações sustentáveis; posteriormente é descrita a metodologia da pesquisa. Por fim, são apresentados os resultados e discussões e a conclusão. 


\section{REFERENCIAL TEÓRICO}

A seguir, serão descritos o referencial teórico sobre licitações públicas, compras governamentais e licitações sustentáveis.

\section{I LICITAÇÕES PÚBLICAS}

A Constituição Federal (1988), no seu art. 37, inciso XXI, descreve a previsão legal que normatiza aos órgãos públicos que as obras, serviços, compras e alienações sejam feitos via processo licitatório, assegurando igualdade de condições a todos os concorrentes.

Para regular o art. 37, inciso XXI, da Constituição Federal, criou-se a Lei n 8.666 , de 21 de junho de 1993 (BRASIL, 1993), e suas alterações, que dispõe sobre as normas gerais sobre licitações e contratos administrativos pertinentes a obras, serviços, inclusive de publicidade, compras, alienações e locações no âmbito dos Poderes da União, dos Estados, do Distrito Federal e dos Municípios.

A licitação destina-se a garantir o princípio constitucional da isonomia, na escolha da proposta mais vantajosa ao poder público, sendo deveres dos gestores públicos em seus atos administrativos, a observância dos princípios da legalidade, impessoalidade, moralidade, igualdade, publicidade, da probidade administrativa, da vinculação ao instrumento convocatório, do julgamento objetivo e dos que lhes são correlatos (BRASIL, 1993). O Quadro 1 descreve estes princípios constitucionais.

Quadro 1. Princípios constitucionais doutrinadores na execução de processos licitatórios pela Administração Pública

\begin{tabular}{|c|c|}
\hline Princípios & Definição \\
\hline Princípio da isonomia & $\begin{array}{l}\text { Significa dar tratamento igual a todos os interessados. Essa é uma } \\
\text { condição essencial para garantir a competição em todos os procedimentos } \\
\text { licitatórios. }\end{array}$ \\
\hline Princípio da legalidade & $\begin{array}{l}\text { Esse princípio vincula os licitantes e a Administração Publica as regras } \\
\text { estabelecidas nas normas e princípios em vigor, nos procedimentos } \\
\text { de licitação. A licitação deve ser processada na forma da Lei, sem } \\
\text { interferência pessoal da autoridade executora do certame licitatório }\end{array}$ \\
\hline Princípio da impessoalidade & $\begin{array}{l}\text { Esse princípio obriga a Administração a observar nas decisões critérios } \\
\text { objetivos previamente estabelecidos, afastando a discricionariedade e o } \\
\text { subjetivismo na condução dos procedimentos de licitação. O interesse } \\
\text { público está acima do interesses pessoais, com tratamento igual a todos } \\
\text { os licitantes interessados. }\end{array}$ \\
\hline Princípio da moralidade & $\begin{array}{l}\text { A conduta dos licitantes e dos agentes públicos tem de ser, além de lícita, } \\
\text { compatível com a moral, a ética, os bons costumes e as regras da boa } \\
\text { administração. }\end{array}$ \\
\hline Princípio da igualdade & $\begin{array}{l}\text { O gestor não poderá incluir cláusulas que restringem ou frustrem o } \\
\text { caráter competitivo. }\end{array}$ \\
\hline $\begin{array}{l}\text { Princípio da probidade } \\
\text { Administrativa }\end{array}$ & $\begin{array}{l}\text { Refere-se na exigência de atuação ética dos agentes da Administração em } \\
\text { todas as etapas do procedimento. }\end{array}$ \\
\hline Princípio da publicidade & $\begin{array}{l}\text { Refere-se ao direito em permitir que licitantes, órgãos de controle interno } \\
\text { e externo, administradores em geral e cidadãos possam acompanhar e } \\
\text { fiscalizar todos os procedimentos licitatórios. Também relata que todos } \\
\text { os motivos relacionados a decisões proferidas em qualquer etapa do } \\
\text { processo licitatório deve ser exposto ao acesso de qualquer cidadão. }\end{array}$ \\
\hline $\begin{array}{l}\text { Princípio da vinculação ao } \\
\text { instrumento convocatório }\end{array}$ & $\begin{array}{l}\text { Obriga a Administração e o licitante a observarem as normas e condições } \\
\text { estabelecidas no ato convocatório. Nada poderá ser criado ou feito sem } \\
\text { que haja previsão no instrumento de convocação. }\end{array}$ \\
\hline $\begin{array}{l}\text { Princípio do julgamento } \\
\text { Objetivo }\end{array}$ & $\begin{array}{l}\text { Esse princípio significa que o administrador deve observar critérios } \\
\text { objetivos, definidosnoatoconvocatório, parajulgamentodadocumentação } \\
\text { e das propostas. Afasta a possibilidade de o julgador utilizar-se de fatores } \\
\text { subjetivos ou de critérios não previstos no instrumento de convocação, } \\
\text { ainda que em beneficio da própria Administração. }\end{array}$ \\
\hline
\end{tabular}

Fonte: Brasil (1993); Brasil (2010b); e Alexandrino e Paulo (2011). 
Para Mello (2012), as compras governamentais, diferentemente dos particulares que possuem ampla liberdade para adquirir bens, alienar, locar bens ou contratar serviços, o poder público ao fazê-las, deve adotar um procedimento preliminar rigorosamente determinado e preestabelecido em conformidade com a lei.

Alexandrino e Paulo (2011) reforçam que a licitação é a explicita concorrência isonômica a fim de obter a proposta mais vantajosa aos interesses da administração para a celebração do contrato com particular vencedor do certame licitatório, a fim de atender a necessidade descrita no objeto da licitação.

A licitação configura-se num procedimento administrativo, em que as entidades governamentais abrem aos interessados a oportunidade de travar determinadas relações de conteúdo patrimonial, selecionando a proposta mais vantajosa para celebrar o contrato de seu interesse (MELLO, 2012).

Di Pietro (2012), afirma que a licitação é um mecanismo em que a administração pública abre a todos os interessados, de acordo com prerrogativas contidas no instrumento convocatório, de apresentar propostas a fim de atender as necessidades das entidades governamentais.

O objetivo principal da licitação é de atender ao interesse público, sendo que requesitos, especialmente relacionados a capacidade técnica e econômico-financeira da empresa licitante, a qualidade do produto e valor do objeto, devem ser considerados (BRASIL, 2010b).

\section{I.I. ModalidAdes E TIPOS DE LICITAÇÕES PÚBLICAS}

A Lei de Licitações determina que estejam sob o regime desta, sujeitos a regra de licitar, além dos órgãos da administração direta, os fundos especiais, as autarquias, as fundações públicas, as empresas públicas, as sociedades de economia mista e demais entidades controladas direta ou indiretamente pela União, Estados, Distrito Federal e Municípios (BRASIL, 1993). Esta lei traz em seu conteúdo, definições que melhor elucidam termos utilizados nos processos de contratação e aquisição de bens e serviços por parte da administração pública, sendo descritos no Quadro 2.

Quadro 2. Definições básicas utilizadas nos processos licitatórios

\begin{tabular}{|c|l|}
\hline Termo & \multicolumn{1}{c|}{ Conceito } \\
\hline Obra & $\begin{array}{l}\text { Refere-se a toda construção, reforma, fabricação, recuperação ou ampliação, } \\
\text { realizada por execução direta ou indireta. }\end{array}$ \\
\hline Serviço & $\begin{array}{l}\text { Refere-se a toda atividade destinada a obter determinada utilidade de interesse } \\
\text { para a Administração, tais como: demolição, conserto, instalação, montagem, } \\
\text { operação, conservação, reparação, adaptação, manutenção, transporte, locação de } \\
\text { bens, publicidade, seguro ou trabalhos técnico-profissionais. }\end{array}$ \\
\hline Compra & $\begin{array}{l}\text { Refere-se a toda aquisição remunerada de bens para fornecimento de uma só vez } \\
\text { ou parcialmente. }\end{array}$ \\
\hline Alienação & Refere-se a toda transferência de domínio de bens a terceiros. \\
\hline
\end{tabular}

Fonte: Adaptado de Brasil (1993).

Depois de definido o objeto de licitação a que se deseja contratar, se faz necessário uma estimativa de preços junto ao mercado atinente ao objeto proposto, a verificação de previsão orçamentária para a eventual contratação e a adequação das peculiaridades dos bens ou serviços a uma modalidade de licitação (BRASIL, 2010b). O Quadro 3 elucida as modalidades de licitação públicas. 
Quadro 3. Caracterização das modalidades de licitação públicas

\begin{tabular}{|c|c|c|c|}
\hline Modalidade & Definiçãa & $\begin{array}{c}\text { Obras e } \\
\text { serviços de } \\
\text { engenharia }\end{array}$ & $\begin{array}{l}\text { Compras } \\
\text { e demais } \\
\text { serviços }\end{array}$ \\
\hline Concorrência & $\begin{array}{l}\text { É a modalidade de licitação entre quaisquer } \\
\text { interessados que, na fase inicial de habilitação } \\
\text { preliminar, comprovem possuir os requisitos } \\
\text { mínimos de qualificação exigidos no edital } \\
\text { para execução de seu objeto. }\end{array}$ & $\begin{array}{l}\text { acima de } \mathrm{R} \$ \\
1.500 .000,00\end{array}$ & $\begin{array}{c}\text { acima de } \mathrm{R} \$ \\
650.000,00\end{array}$ \\
\hline $\begin{array}{l}\text { Tomada de } \\
\text { preços }\end{array}$ & $\begin{array}{l}\text { É a modalidade de licitação entre interessados } \\
\text { devidamente cadastrados ou que atenderem } \\
\text { a todas as condições exigidas para } \\
\text { cadastramento até o terceiro dia anterior à } \\
\text { data do recebimento das propostas, observada } \\
\text { a necessária qualificação. }\end{array}$ & $\begin{array}{c}\text { até } \mathrm{R} \$ \\
1.500 .000,00\end{array}$ & $\begin{array}{c}\text { até } \mathrm{R} \$ \\
650.000,00\end{array}$ \\
\hline Convite & $\begin{array}{l}\text { É a modalidade de licitação entre } \\
\text { interessados do ramo pertinente ao seu } \\
\text { objeto, cadastrados ou não, escolhidos e } \\
\text { convidados em número mínimo de } 3 \text { (três) } \\
\text { pela unidade administrativa, a qual } \\
\text { afixará, em local apropriado, cópia do } \\
\text { instrumento convocatório e o estenderá } \\
\text { aos demais cadastrados na correspondente } \\
\text { especialidade que manifestarem seu } \\
\text { interesse com antecedência de até } 24 \\
\text { (vinte e quatro) horas da apresentação das } \\
\text { propostas. }\end{array}$ & $\begin{array}{c}\text { até } \mathrm{R} \$ \\
150.000,00\end{array}$ & até $\mathrm{R} \$ 80.000,00$ \\
\hline Pregão & $\begin{array}{l}\text { É a modalidade de licitação realizada entre } \\
\text { interessados do ramo de que trata o objeto } \\
\text { da licitação que comprovem possuir os } \\
\text { requisitos mínimos de qualificação exigidos } \\
\text { no edital, em que a disputa pelo } \\
\text { fornecimento de bens ou serviços comuns } \\
\text { e feita } \\
\text { em sessão pública. Pode ser presencial ou } \\
\text { eletrônico. Destina-se exclusivamente a } \\
\text { contratação de bens e serviços comuns. }\end{array}$ & Não se aplica & $\begin{array}{l}\text { Independe } \\
\text { do valor } \\
\text { estimado para } \\
\text { a contratação }\end{array}$ \\
\hline
\end{tabular}

Fonte: Elaborado a partir de Brasil (1993) e Brasil (2002). 
Vale ressaltar ainda, que existem modalidades de licitação complementares aos especificados no Quadro 3, como o concurso, que visa selecionar trabalhos técnicos, científicos ou artísticos, por meio de prêmios ou remunerações, aos vencedores, com critérios previamente descritos em instrumento convocatório e o leilão que objetiva aos interessados a venda de bens móveis inservíveis, ou produtos legalmente apreendidos, penhorados, ou para a alienação, oriundos de procedimentos judiciais ou doação em pagamento, a quem oferecer lance igual ou maior ao valor da avaliação do objeto em questão (BRASIL, 1993).

Entretanto, existem situações em que a regra de licitar é dispensada, previstas na Lei $\mathrm{n}^{\circ} 8.666$, de 1993 (BRASIL, 1993). Na licitação dispensável, não haverá licitação de acordo com o art. 17, I e II da referida lei. Dispensa de licitação, é quando a lei permite hipóteses para que a Administração deixe de licitar e a inexigibilidade de licitação quando há impossibilidade jurídica de competição entre os contratantes, quer pela natureza específica do negócio, quer pelos objetivos sociais visados pela Administração, previsto no art 25 da Lei de Licitações.

Meirelles (2010) pondera que tanto para a realização da dispensa e da inexigibilidade de licitação, devem constar nos autos do processo a motivação devidamente justificada, com elementos que ratifiquem a opção por tais procedimentos para eventuais contratações por parte da administração pública.

Quanto aos tipos de licitação, refere-se ao critério de julgamento utilizado pela administração para seleção da proposta mais vantajosa, conforme descreve o art. 45 da Lei n ${ }^{\circ}$ 8.666, de 1993 (BRASIL, 1993). Alexandrino e Paulo (2011) relatam que o tipos de licitação são os critérios objetivos que serão observados para o julgamento das propostas entre as modalidades de licitação existentes, excetuando-se a modalidade concurso. O Quadro 4 descreve os tipos de critérios adotados no julgamento das propostas nos certames licitatórios.

Quadro 4. Tipos de critérios adotados no julgamento das propostas nos certames licitatórios públicos.

\begin{tabular}{|c|l|}
\hline Tipo & \multicolumn{1}{c|}{ Definição } \\
\hline Menor Preço & O critério de seleção da proposta é o menor preço ofertado. \\
\hline Melhor Técnica & $\begin{array}{l}\text { O critério de seleção da proposta mais vantajosa para administração } \\
\text { tem por base fatores de ordem técnica. }\end{array}$ \\
\hline Técnica e Preço & $\begin{array}{l}\text { O critério de seleção da proposta mais vantajosa para a Administração } \\
\text { tem por base a maior media ponderada, considerando-se as notas } \\
\text { obtidas nas propostas de preço e técnica. }\end{array}$ \\
\hline
\end{tabular}

Fonte: Brasil (2010b).

O tipo de licitação "menor preço" é geralmente utilizada para a compra de bens, execução de obras ou prestação de serviços, onde as ofertas são colocadas em ordem crescente e em caso de empate realizar-se-á um sorteio de desempate em ato público. No tipo "melhor técnica" as propostas serão classificadas e avaliadas de acordo com critérios objetivos preestabelecidos no instrumento convocatório, mediante ponderação da nota e peso atribuídos a cada um dos fatores estabelecidos. No tipo "técnico e preço" as propostas são classificadas de acordo com os critérios técnicos e o preço preestabelecido no instrumento convocatório, mediante ponderação da nota e peso atribuídos a cada um dos fatores estabelecidos (BRASIL, 2010b).

\subsection{COMPRAS GOVERNAMENTAIS: O PODER DO ESTADO NO FOMENTO A MUDANÇAS}

O Estado em suas compras públicas age como fator de estímulo no processo produtivo, promovendo a busca pela qualidade, a produtividade, a inovação tecnológica, adequando o mercado interno a suas necessidades, gerando consequências positivas como aumento na oferta de empregos, promovendo a competitividade entre empresas, e colaborando para o desenvolvimento nacional.

As compras governamentais realizadas no Brasil movimentaram, em 2012, em torno de 72 bilhões de reais, mobilizando diversos setores da economia (BRASIL, 2014a). Assim, o poder público, em suas compras públicas, apresenta um alto grau de influência no mercado interno, evidenciando o 
papel do Estado de indutor de mudanças nos processos produtivos de diversos setores da economia.

Entretanto, as compras governamentais estão inseridas numa nova realidade, que se caracteriza por clientes comprometidos e dispostos a interagir com organizações éticas e que atuem de forma ambientalmente responsável (TACHIZAWA, 2011).

Estas mudanças de hábitos dos consumidores foram fundamentais na elaboração de mecanismos objetivos, despertando nas organizações o interesse pela gestão ambiental (SEIFFERT, 2011).

O grande volume de informações ambientais existentes na mídia atual faz com que a sociedade esteja em alerta com problemas ecológicos atuais, e as empresas perceberam que a adaptação a esta nova realidade, confere vantagens competitivas no mercado (MOURA, 2008).

Segundo dados da pesquisa realizada por Akatu (2013), 59\% dos entrevistados "concordam muito" e 39\% simplesmente "concordam" que o governo deveria comprar somente de empresas social e ambientalmente corretas, reforçando assim o desejo e a preocupação da sociedade com os problemas relacionados ao meio ambiente e qualidade de vida das pessoas. Juntem-se a isso, as pressões internacionais por mudanças no uso dos recursos naturais, visto que os padrões insustentáveis de produção e consumo, só favorecem o acirramento das desigualdades regionais.

Diante deste cenário, a inclusão dos impactos sociais e ambientais nas agendas dos líderes internacionais para revisão do padrão do crescimento populacional e das políticas econômicas desenvolvidas, fez com que a sustentabilidade surgisse como uma necessidade a qual precisava migrar do plano teórico para se tornar em ações práticas e concretas.

O poder público brasileiro ciente desta nova realidade percebeu que suas ações políticas devem estar alinhadas a critérios socioambientais, visto que, a sociedade espera dos gestores públicos além de adoção de princípios de eficiência e economicidade na aplicação dos recursos públicos, ações que estejam em consonância com o equilíbrio ambiental, para que os direitos constitucionais tais como, o desenvolvimento econômico, social e proteção ao meio ambiente, e uma consequente melhora na qualidade de vida, sejam assegurados a todos.

A utilização de recursos públicos na aquisição de bens e serviços gera grande impacto na economia (BRASIL, 2009). Devido ao seu poder de compra, o Estado pode referenciar o mercado quanto ao perfil de suas compras públicas, promovendo uma competição na indústria e mudanças significativas em todas as etapas da cadeia produtiva, contribuindo para mudanças no padrão produtivo e na forma de se comprar e consumir (BETIOL et al., 2012).

Nesse sentido, cria-se um fator positivo que pode aliar ao processo produtivo a questão socioambiental, que é a adoção dos princípios de sustentabilidade nas aquisições públicas (BRASIL, 2013a).

\subsection{LICITAÇÕES SUSTENTÁVEIS}

O meio ambiente como tema de políticas públicas, apresenta características que o torna diferente dos demais temas abordados na gestão de um Estado, visto que a política ambiental trata de problemas que englobam bens comuns, de uso coletivo e que são de ação global. Cabe ao Estado, manter o equilíbrio entre crescimento econômico, proteção ambiental e conservação da biodiversidade, promovendo um mercado mais inovador e uma economia mais verde e inclusiva.

Assim, um dos mecanismos que a administração pública pode adotar para implementar ações ambientalmente corretas, com grande abrangência e incentivadora a mudanças em escala econômica, na produção e consumo, e como forma de conceituação para os problemas ambientais é a adoção de critérios socioambientais em suas compras. A Lei federal $\mathrm{n}^{\circ}$ 12.349/2010 (BRASIL, 2010c) alterou o art. $3^{\circ}$ da Lei federal 8.666/93 (BRASIL, 1993), trazendo em seu texto que a licitação é uma forma de viabilizar o desenvolvimento nacional sustentável.

As compras verdes são um processo onde a contratação de bens, serviços e obras, consideram os custos efetivos, em longo prazo, visando benefícios econômicos para sociedade, com um mínimo de dano ao meio ambiente (BIDERMAN et al., 2008). Em um processo de licitação sustentável, muda-se o foco do objetivo principal de uma licitação que levam em conta critérios quantitativos (em função do preço) e adotam-se também critérios qualitativos (em função as características do objeto), ou seja, a relação benefício-custo é a doutrinadora de ações.

As licitações sustentáveis não surgem como uma nova modalidade de licitação, e sim, como 
uma maneira diferente de se executar as modalidades de licitação já existentes na legislação, pois a busca pela proposta de menor preço e que atenda a necessidade da administração pública deve atender também critérios socioambientais.

As compras verdes configuram-se no ponto da intersecção entre três variáveis: a busca pelo melhor preço, combinado a atenção aos critérios ambientais, sem frustrar a competitividade, de maneira que ao optar pela aquisição de um produto sustentável não venham restringir a concorrência. Isso ocorre porque os objetivos da licitação sustentável visam a ser instrumento de ação positiva de integração de critérios ambientais e inovador na escala de produção e consumo da economia nacional, bem como ser eficientes, não elevando os custos neste tipo de contratação, haja visto que o enfoque principal recai na aquisição de produtos e serviços ecológicos (BETIOL et. al., 2012).

Kotler e Keller (2012) definem produto como algo que é oferecido no mercado, para a apreciação, aquisição ou consumo a fim de atender alguma necessidade ou desejo, nesta perspectiva se enquadram os bens físicos e serviços. Já produto ecológico é aquele que além de cumprir as mesmas funções dos produtos equivalentes, causa impactos ambientais negativos inferiores durante o seu ciclo de vida (DIAS, 2012). O Quadro 5 aponta os critérios ambientais que caracterizam os produtos ecológicos.

Quadro 5. Características ambientais dos produtos ecológicos

\begin{tabular}{|l|}
\hline \multicolumn{1}{|c|}{ Característica ambientais } \\
\hline Produtos feitos de bens reciclados \\
\hline Produtos que pode ser reciclados ou reutilizados \\
\hline Produtos eficientes energeticamente \\
\hline Produtos com embalagens ambientalmente responsáveis \\
\hline Produtos orgânicos \\
\hline Serviços que alugam ou emprestam produtos \\
\hline Produtos certificados \\
\hline
\end{tabular}

Fonte: Adaptado de Dias (2012).

A Instrução Normativa $n^{\circ}$ 01, do Ministério do Planejamento, Orçamento e Gestão, de 19 de janeiro de 2010 é o instrumento que detalha os critérios ambientais nas licitações na forma da lei, destacando-se os atributos tais como a eficiência energética, a redução do consumo de água, o uso de energia renovável, a gestão de resíduos, produtos biodegradáveis e comprovação de origem de madeiras, como exigências ambientais para as contratações públicas, desde que respeitados os princípios da competitividade e isonomia. (BRASIL, 2013a; BRASIL, 2010a).

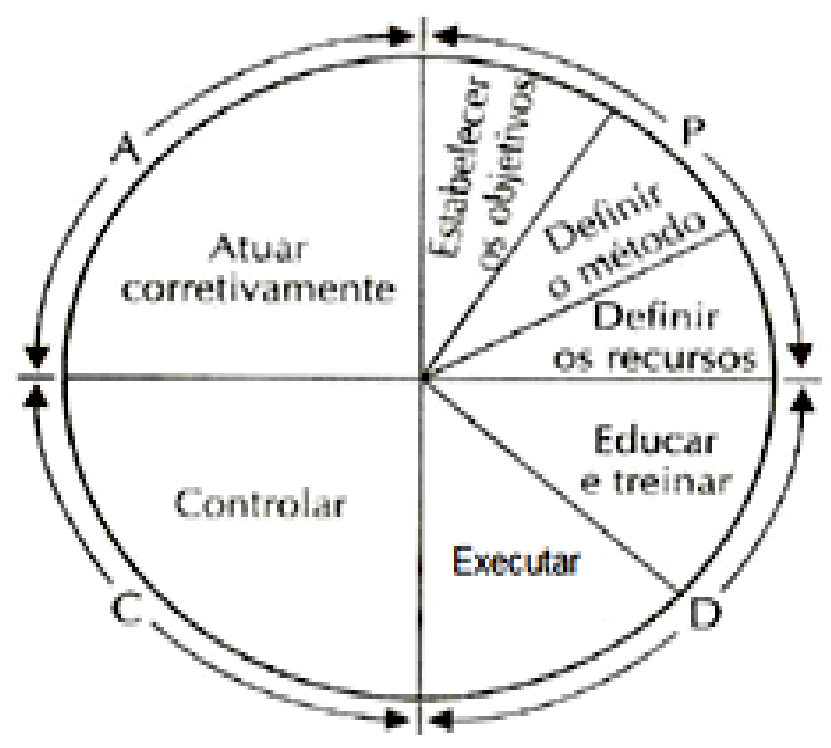

Figura 1. Ciclo PDCA

Fonte: Adaptado de Maranhão (2006). 
Além do mais, o poder público pode utilizar-se das compras públicas sustentáveis, como uma forma de efetivar as normas contidas na Convenção Organizacional do Trabalho (OIT), relativas ao trabalho, emprego, seguridade social e direitos humanos nas suas contratações públicas, onde vários fatores sociais e de proteção a dignidade da vida humana ficam assegurados. (BRASIL, 2013a; BARBIERI, 2012).

Como uma forma de auxiliar os gestores públicos na implementação e execução das compras públicas sustentáveis, a metodologia do ciclo PDCA (Figura 1) é uma ferramenta que pode auxiliar na efetivação das licitações sustentáveis dentro de uma organização. As etapas do ciclo PDCA são descritas no Quadro 6.

Quadro 6. Etapas do ciclo PDCA nas licitações sustentáveis

\begin{tabular}{|c|c|c|}
\hline \multicolumn{2}{|r|}{ Etapa } & Ação \\
\hline \multirow[b]{2}{*}{ Planejar } & Definir metas & Buscar eficiência e eficácia nas aquisições sustentáveis. \\
\hline & Definir métodos & $\begin{array}{l}\text { Determinar planos de capacitação dos envolvidos no } \\
\text { processo de compras de um órgão; Elaboração de planos de } \\
\text { educação ambiental. }\end{array}$ \\
\hline \multirow[t]{2}{*}{ Executar } & Educar e treinar & $\begin{array}{l}\text { Capacitar o pessoal envolvido no processo de compras e } \\
\text { demais integrantes da organização com ações de educação } \\
\text { ambiental; Fornecer subsídios aos servidores responsáveis } \\
\text { pelo processo de compras de alternativas mais sustentáveis } \\
\text { na elaboração de requisições e especificações técnicas de } \\
\text { produtos e serviços necessários a rotina da organização; } \\
\text { Dar ciência a todos integrantes da organização as exigências } \\
\text { das legislações pertinentes as licitações; Fomentar ações de } \\
\text { mudança para comportamentos mais sustentáveis dentro da } \\
\text { organização. }\end{array}$ \\
\hline & Executar & $\begin{array}{l}\text { Executar as etapas de um processo licitatório, com o } \\
\text { incremento dos critérios socioambientais, em conformidade } \\
\text { com as legislações pertinentes. }\end{array}$ \\
\hline Verificar & Verificar Resultados & $\begin{array}{l}\text { Verificar se as contratações sustentáveis atenderam as } \\
\text { expectativas dos setores que demandaram os produtos e } \\
\text { serviços, e estes estão em conformidade com as especificações } \\
\text { de qualidade aos produtos e serviços similares convencionais } \\
\text { e adequados as exigências impostas por legislações. }\end{array}$ \\
\hline Ação & Ações corretivas & $\begin{array}{l}\text { Verificar as etapas que necessitam melhorias e acumular } \\
\text { ensinamentos de melhorias para futuras licitações. }\end{array}$ \\
\hline
\end{tabular}

Fonte: Elaborado a partir de Maranhão (2006); Slack et al.; (2008); ICLEI (2007);Moura (2008).

Assim, o cerne do sucesso dentro de uma organização está em demonstrar aos envolvidos no processo de execução de uma licitação os benefícios na parte ambiental, social e financeira ao se adotar princípios de sustentabilidade na execução das compras públicas. Atualmente, fatores como preço, prazo e qualidade inerentes as licitações convencionais devem ser complementados com os critérios de sustentabilidade na execução das compras públicas (BETIOL et al., 2012).

Como forma de ratificar as ações dos gestores públicos ao se realizar licitações sustentáveis, o Quadro 7 mostra as legislações federais onde fundamentam-se as licitações sustentáveis. 
Quadro 7. Legislações aplicáveis as licitações sustentáveis

\begin{tabular}{|c|c|}
\hline Ano & Legislações e suas principais contribuições \\
\hline 1966 & Lei $\mathrm{n}^{\circ} 5.106 / 1966$ - Dispõe sobre os incentivos fiscais concedidos a empreendimentos florestais. \\
\hline 1981 & $\begin{array}{l}\text { Lei n }{ }^{\circ} 6.938 / 1981 \text { - Dispõe sobre a Política Nacional do Meio Ambiente, seus fins e mecanismos } \\
\text { de formulação e aplicação, e dá outras providências. }\end{array}$ \\
\hline 1985 & $\begin{array}{l}\text { Lei } \mathrm{n}^{\circ} 7347 / 1985 \text { - Disciplina a ação civil pública de responsabilidade por danos causados ao } \\
\text { meio-ambiente, ao consumidor, a bens e direitos de valor artístico, estético, histórico, turístico } \\
\text { e dá outras providências. }\end{array}$ \\
\hline 1988 & $\begin{array}{l}\text { Constituição Federal Brasileira - Instituiu no artigo } 225 \text { o direito de todos ao meio ambiente } \\
\text { ecologicamente equilibrado, bem de uso comum do povo e essencial à sadia qualidade de vida. }\end{array}$ \\
\hline 1990 & $\begin{array}{l}\text { Decreto federal no 99.658/1990 - Regulamenta, no âmbito da Administração Pública Federal, } \\
\text { o reaproveitamento, a movimentação, a alienação e outras formas de desfazimento de material. }\end{array}$ \\
\hline 1992 & $\begin{array}{l}\text { Decreto federal } n^{\circ} 563 / 1992 \text { - Institui o Programa Piloto para a Proteção das Florestas } \\
\text { Tropicais do Brasil e cria a Comissão de Coordenaça. }\end{array}$ \\
\hline 1993 & $\begin{array}{l}\text { Lei federal no }{ }^{\circ} \text { 8.666/1993 - Regulamenta o art. 37, inciso XXI, da Constituição Federal, institui } \\
\text { normas para licitações e contratos da Administração Pública e dá outras providências. }\end{array}$ \\
\hline \multirow{4}{*}{1994} & $\begin{array}{l}\text { Lei } \mathrm{n}^{\circ} 8.883 / 1994 \text { - Altera dispositivo da Lei } 8.666 \text { de } 21 \text { de junho de } 1993 \text {, que regulamenta } \\
\text { o art. 37, inciso XXI, da Constituição Federal, institui normas para licitaços e dá outras } \\
\text { providências. }\end{array}$ \\
\hline & $\begin{array}{l}\text { Decreto federal } \mathrm{n}^{\circ} \text { 1.048/1994 - Dispõe sobre o Sistema de Administração dos Recursos de } \\
\text { Informação e Informática, da Administração Pública Federal, e dá outras providências. }\end{array}$ \\
\hline & $\begin{array}{l}\text { Decreto federal n }{ }^{\circ} 1.094 / 1994 \text { - Dispõe sobre o Sistema de Serviços Gerais (SISG) dos órgãos } \\
\text { civis da Administração Federal direta, das autarquias e fundações públicas, e dá outras } \\
\text { providências. }\end{array}$ \\
\hline & $\begin{array}{l}\text { Resolução CONAMA n }{ }^{\circ} \text { 20/1994 - Dispões sobre a instituição do Selo Ruído de uso obrigatório } \\
\text { para aparelhos eletrodomésticos que geram ruído no seu funcionamento. }\end{array}$ \\
\hline \multirow{4}{*}{1998} & $\begin{array}{l}\text { Lei } \mathrm{n}^{\circ} 9.648 / 1998 \text { - Altera dispositivos das Leis } \mathrm{n}^{\circ} 3.890-\mathrm{A} \text {, de } 25 \text { de abril de } 1961, \mathrm{n}^{\circ} 8.666 \text {, de } \\
21 \text { de junho de } 1993, \mathrm{n}^{\circ} 8.987 \text {, de } 13 \text { de fevereiro de } 1995, \mathrm{n}^{\circ} 9.074 \text {, de } 7 \text { de julho de } 1995, \mathrm{n}^{\circ} \\
\text { 9.427, de } 26 \text { de dezembro de } 1996 \text {, e autoriza o Poder Executivo a promover a reestruturação da } \\
\text { Centrais Elétricas Brasileiras - ELETROBRÁS e de suas subsidiárias e dá outras providências. }\end{array}$ \\
\hline & $\begin{array}{l}\text { Lei } \mathrm{n}^{\circ} 9.605 / 1998 \text { - Dispõe sobre as sanções penais e administrativas derivadas de condutas e } \\
\text { atividades lesivas ao meio ambiente, e dá outra providência. }\end{array}$ \\
\hline & $\begin{array}{l}\text { Lei } n^{0} 9.660 / 1998 \text { - Dispõe sobre a substituição gradual da frota de veículos e dá outras } \\
\text { providências. }\end{array}$ \\
\hline & $\begin{array}{l}\text { Decreto federal } n^{\circ} \text { 2.783/1998 - Dispõe sobre proibição de aquisição de produtos ou } \\
\text { equipamentos que contenham ou façam uso das Substâncias que Destroem a Camada de } \\
\text { Ozônio - SDO, pelos órgãos e pelas entidades da Administração Pública Federal direta, } \\
\text { autárquica e fundacional, e dá outras providências. }\end{array}$ \\
\hline
\end{tabular}


Quadro 7. continuação...

\begin{tabular}{|c|c|}
\hline Ano & Legislações e suas principais contribuições \\
\hline 1999 & $\begin{array}{l}\text { Resolução CONAMA no 257/1999 - Estabelece que pilhas e baterias que contenham em } \\
\text { suas composições chumbo, cádmio, mercúrio e seus compostos, tenham os procedimentos de } \\
\text { reutilização, reciclagem, tratamento ou disposição final ambientalmente adequados. }\end{array}$ \\
\hline \multirow{2}{*}{2001} & $\begin{array}{l}\text { Lei } \mathrm{n}^{\circ} 10.295 / 2001 \text { - Dispõe sobre a Política Nacional de Conservação e Uso Racional de } \\
\text { Energia e dá outras providências. }\end{array}$ \\
\hline & $\begin{array}{l}\text { Decreto federal } n^{\circ} 4.059 / 2001 \text { - Regulamenta a Lei no } 10.295 \text { de } 17 \text { de outubro de } 2001 \text {, que } \\
\text { dispõe sobre a Política Nacional de Conservação e Uso Racional de Energia, e dá outras } \\
\text { providências. }\end{array}$ \\
\hline \multirow{3}{*}{2002} & $\begin{array}{l}\text { Lei federal } n^{\circ} 10.520 / 2002 \text { - Institui, no âmbito da União, Estados, Distrito Federal e } \\
\text { Municípios, nos termos do art. } 37 \text {, inciso XXI, da Constituição Federal, modalidade de licitação } \\
\text { denominada pregão, para aquisição de bens e serviços comuns, e dá outras providências. }\end{array}$ \\
\hline & $\begin{array}{l}\text { Decreto federal no } 4.131 / 2002 \text { - Dispõe sobre medidas emergenciais de redução do consumo } \\
\text { de energia elétrica no âmbito da Administração Pública Federal. }\end{array}$ \\
\hline & $\begin{array}{l}\text { Resolução CONAMA n }{ }^{\circ} 307 / 2002 \text { - Estabelece diretrizes, critérios e procedimentos para a } \\
\text { gestão dos resíduos da construção civil. }\end{array}$ \\
\hline \multirow[t]{2}{*}{2003} & Lei n $10.831 / 2003$ - Dispõe sobre a agricultura orgânica. \\
\hline & Lei n $10.696 / 2003$ - Cria o Programa de Aquisição de Alimentos. \\
\hline 2005 & $\begin{array}{l}\text { Decreto n }{ }^{\circ} 5.450 / 2005 \text { - Regulamenta o pregão, na forma eletrônica, para aquisição de bens } \\
\text { e serviços comuns. }\end{array}$ \\
\hline \multirow[t]{2}{*}{2006} & $\begin{array}{l}\text { Lei Complementar } n^{\circ} 123 / 2006 \text { - Institui o Estatuto Nacional da Microempresa e da Empresa } \\
\text { de Pequeno Porte; altera dispositivos das Leis no } 8.212 \text { e } 8.213 \text {, ambas de } 24 \text { de julho de } 1991 \text {, } \\
\text { da Consolidação das Leis do Trabalho - CLT, aprovada pelo Decreto-Lei no } 5.452 \text {, de } 1 \text { o de } \\
\text { maio de } 1943 \text {, da Lei no } 10.189 \text {, de } 14 \text { de fevereiro de } 2001 \text {, da Lei Complementar no } 63 \text {, de } \\
11 \text { de janeiro de } 1990 \text {; e revoga as Leis no } 9.317 \text {, de } 5 \text { de dezembro de } 1996 \text {, e } 9.841 \text {, de } 5 \text { de } \\
\text { outubro de } 1999 \text {. }\end{array}$ \\
\hline & $\begin{array}{l}\text { Decreto federal } n^{\circ} 5.940 / 2006 \text { - Institui a separação dos resíduos recicláveis descartados pelos } \\
\text { órgãos e entidades da administração pública federal direta e indireta, na fonte geradora, e a } \\
\text { sua destinação às associações e cooperativas dos catadores de materiais recicláveis, e dá outras } \\
\text { providências. }\end{array}$ \\
\hline 2007 & $\begin{array}{l}\text { Decreto federal } \mathrm{n}^{\circ} 6.204 / 2007 \text { - Regulamenta o tratamento favorecido, diferenciado e } \\
\text { simplificado para as microempresas e empresas de pequeno porte nas contratações públicas } \\
\text { de bens, serviços e obras, no âmbito da administração pública federal. }\end{array}$ \\
\hline \multirow[t]{2}{*}{2008} & $\begin{array}{l}\text { Portaria } \mathrm{n}^{\circ} \text { 61/2008-MMA - Estabelece práticas de sustentabilidade ambiental a serem } \\
\text { observadas pelo Ministério do Meio Ambiente e suas entidades vinculadas quando das } \\
\text { compras públicas sustentáveis e dá outras providências. }\end{array}$ \\
\hline & $\begin{array}{l}\text { Resolução CONAMA n }{ }^{\circ} 401 / 2008 \text { - Estabelece os limites máximos de chumbo, cádmio e } \\
\text { mercúrio para pilhas e baterias comercializadas no território nacional e os critérios e padrões } \\
\text { para o seu gerenciamento ambientalmente adequado, e dá outras providências. }\end{array}$ \\
\hline
\end{tabular}


Quadro 7. continuação...

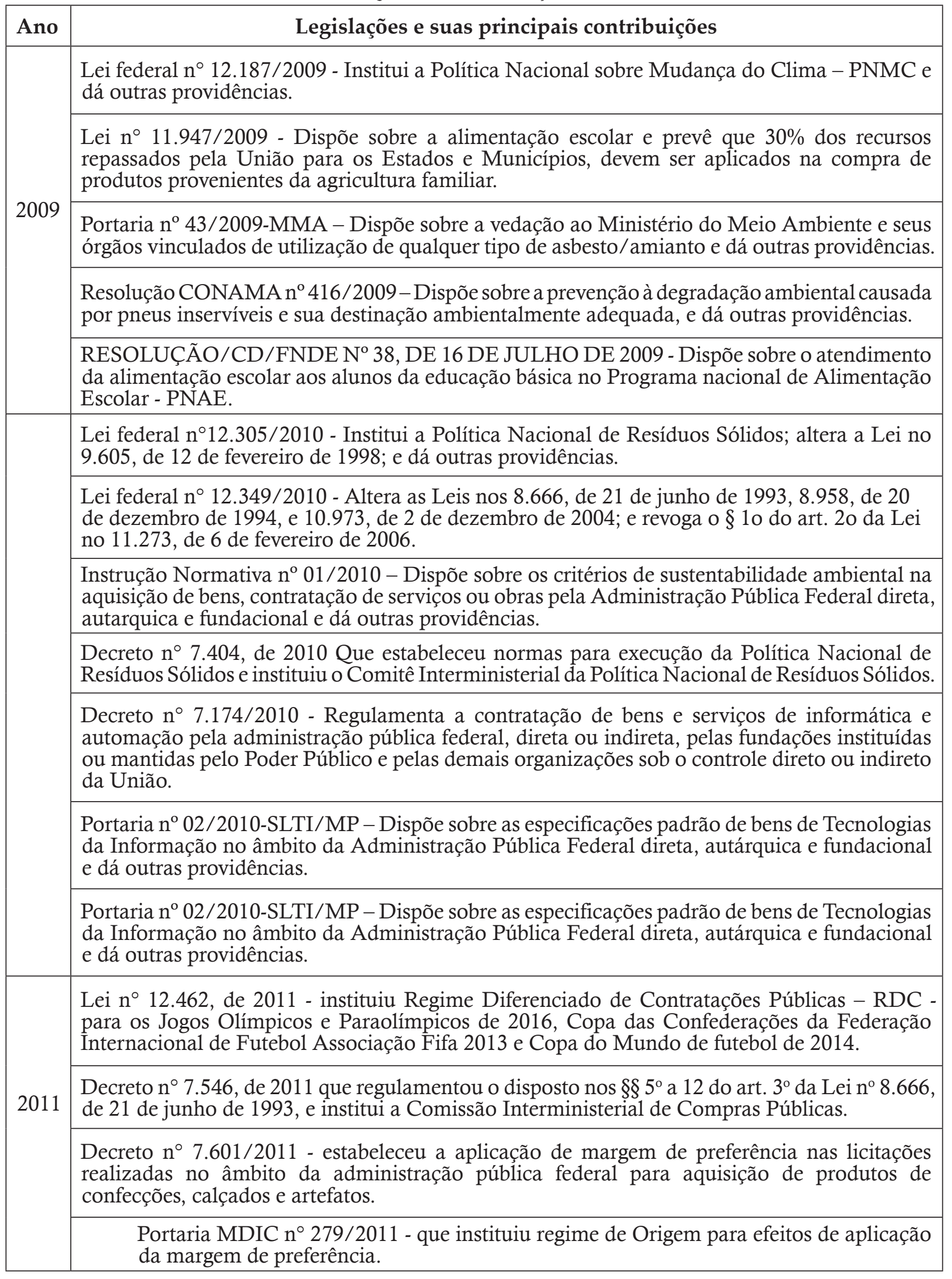


Quadro 7. continuação...

\begin{tabular}{|c|c|}
\hline Ano & Legislações e suas principais contribuições \\
\hline \multirow{7}{*}{2012} & $\begin{array}{l}\text { Lei } n^{\circ} 12.651 / 2012 \text { - Dispõe sobre a proteção da vegetação nativa; altera as Leis } n^{\text {os }} 6.938 \text {, de } \\
31 \text { de agosto de } 1981,9.393 \text {, de } 19 \text { de dezembro de } 1996 \text {, e } 11.428 \text {, de } 22 \text { de dezembro de } 2006 \text {; } \\
\text { revoga as Leis } n^{\text {os }} 4.771 \text {, de } 15 \text { de setembro de } 1965 \text {, e } 7.754 \text {, de } 14 \text { de abril de } 1989 \text {, e a Medida } \\
\text { Provisória } n^{\circ} 2.166-67 \text {, de } 24 \text { de agosto de } 2001 \text {; e dá outras providências. }\end{array}$ \\
\hline & $\begin{array}{l}\text { Lei } n^{\circ} 12.651 / 2012 \text { - Dispõe sobre a proteção da vegetação nativa; altera as Leis } n^{\text {os }} 6.938 \text {, de } \\
31 \text { de agosto de } 1981,9.393 \text {, de } 19 \text { de dezembro de } 1996 \text {, e } 11.428 \text {, de } 22 \text { de dezembro de } 2006 \text {; } \\
\text { revoga as Leis } n^{\text {os }} 4.771 \text {, de } 15 \text { de setembro de } 1965 \text {, e } 7.754 \text {, de } 14 \text { de abril de } 1989 \text {, e a Medida } \\
\text { Provisória } n^{\circ} 2.166-67 \text {, de } 24 \text { de agosto de } 2001 \text {; e dá outras providências. }\end{array}$ \\
\hline & $\begin{array}{l}\text { Decreto federal } n^{\circ} 7.746 / 2012 \text { - Regulamenta o art. 3o da Lei no } 8.666 \text {, de } 21 \text { de junho de } \\
1993 \text {, para estabelecer critérios, práticas e diretrizes para a promoção do desenvolvimento } \\
\text { nacional sustentável nas contratações realizadas pela administração pública federal, e institui } \\
\text { a Comissão Interministerial de Sustentabilidade na Administração Pública - CISAP. }\end{array}$ \\
\hline & Decreto N7.794/2012 - Instituiu a Política Nacional de Agroecologia e Produção orgânica. \\
\hline & $\begin{array}{l}\text { Decreto } n^{\circ} 7.675 / 2012 \text { - Aprova a Estrutura Regimental e o Quadro Demonstrativo dos Cargos } \\
\text { em Comissão e das Funções Gratificadas do Ministério do Planejamento, Orçamento e Gestão. }\end{array}$ \\
\hline & $\begin{array}{l}\text { Instrução Normativa } n^{\circ} 10 / 2012 \text { - Estabelece regras para elaboração dos Planos de Gestão de } \\
\text { Logística Sustentável de que trata o art. 16, do Decreto n }{ }^{\circ} 7.746 \text {, de } 5 \text { de junho de } 2012 \text {, e dá } \\
\text { outras providências. }\end{array}$ \\
\hline & $\begin{array}{l}\text { MP 573/12 - visa a estimular a indústria nacional por meio da compra de equipamentos por } \\
\text { nove órgãos federais: Educação, Justiça, Saúde, Transportes, Planejamento, Desenvolvimento } \\
\text { Agrário, Defesa, Integração Nacional e Cidades. }\end{array}$ \\
\hline 2013 & $\begin{array}{l}\text { Portaria } n^{\circ} 12 / 2013-\text { SLTI/MP - Prorroga o prazo para elaboração dos Planos de Gestão de } \\
\text { Logística Sustentável - PLS, estabelecidos pela Instrução Normativa no }{ }^{\circ} 10 \text {, de } 12 \text { de novembro } \\
\text { de } 2012 \text {. }\end{array}$ \\
\hline
\end{tabular}

Fonte: Elaborado a partir de Brasil (2013b) e Brasil (2013c).

\subsection{Licitações sustentáveis no Exército Brasileiro}

Segundo o Informativo de Contratações Públicas Sustentáveis (2014), do Ministério do Planejamento, Orçamento e Gestão, em 2012, foram realizados cerca de 1.481 processos licitatórios de aquisição sustentável que movimentaram $R \$ 40$ milhões de reais. Isto representa $0,1 \%$ das compras totais realizadas pelos órgãos públicos federais que utilizam o Sistema Integrado de Administração e Serviço Gerais (SIASG) como ferramenta para suas aquisições. O pregão eletrônico foi à modalidade de licitação mais utilizada nas licitações sustentáveis, representando 99,4\% dos processos licitatórios executados. Desta forma, verifica-se que, a representatividade das licitações sustentáveis está muito abaixo do panorama geral das compras públicas realizadas no Brasil.

No primeiro semestre de 2013, o Ministério da Defesa ficou em segundo lugar dentre os órgãos da administração pública federal com um dos maiores valores despendidos nas compras verdes, representando $20 \%$ do total das aquisições sustentáveis realizadas pelo governo federal) (BRASIL, 2014b).

O Ministério da Defesa é um órgão do governo federal responsável pela direção superior das Forças Armadas, constituídas pela Marinha, pelo Exército e pela Aeronáutica. O Exército brasileiro é uma instituição com alto prestígio junto à sociedade, conforme pesquisa realizada pelo IBOPE - Insti- 
tuto Brasileiro de Opinião Pública e Estatística (2013 - já que as Forças Armadas representam a terceira instituição com maior índice de confiança e credibilidade pelos brasileiros. Sabe-se que o Exército brasileiro, contribui significativamente para este elevado grau depositado pela sociedade, visto que o maior efetivo de militares na ativa entre as três forças é composto aproximadamente por 222.869 mil homens e mulheres, distribuído em todas as unidades federativas e no distrito federal, num total de 1233 organizações militares espalhadas no território nacional (BRASIL, 2013d).

A seguir, será descrita a metodologia utilizada nesta pesquisa.

\section{METODOLOGIA DA PESQUISA}

Apesar de o tema "compras verdes" ser de relevante importância, ainda existem poucos trabalhos que abordam o tema "licitações sustentáveis" e, principalmente, relacionado às instituições do Exército brasileiro.

O presente trabalho adotou a abordagem metodológica proposta por Malhotra (2001), sendo possível caracterizar esta pesquisa como exploratória, pois este tipo de pesquisa visa buscar critérios e ferramentas para melhor compreender um tema qualquer, sendo no caso particular a licitação sustentável, a forma e aplicabilidade dos conceitos ambientais na execução dos processos licitatórios nas instituições do Exército brasileiro.

$\mathrm{Na}$ etapa de levantamento bibliográfico, foram consultados materiais publicados em livros, artigos científicos, dissertações e teses sobre licitação pública, compras governamentais e licitações sustentáveis.

A base de dados da pesquisa configurou-se em dados secundários cujas características podem ser verificadas na Figura 2.

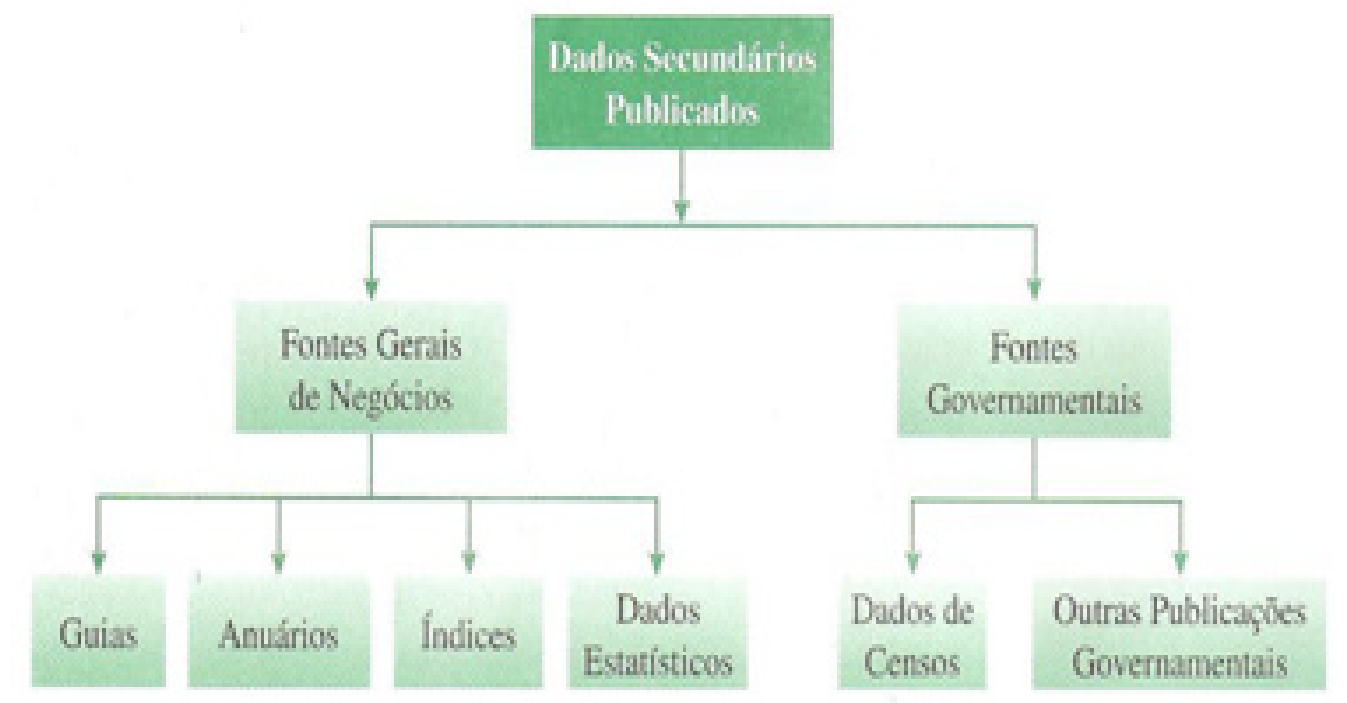

Figura 2. Características das fontes dos dados secundários

Fonte: Malhotra, 2001.

A pesquisa baseou-se na consulta de dados secundários externos, sendo de fontes governamentais. Malhotra (2001) afirma que os dados secundários são dados de fácil acesso e obtenção, poucos dispendiosos e permitem melhor identificar e definir o problema.

Foram analisadas licitações executadas pelas organizações militares do Exército brasileiro que continham algum critério ambiental disponibilizados em COMPRASNET (2013), portal de compras do governo federal, a fim de diagnosticar as características das licitações sustentáveis realizadas pelas instituições.

Também foram consultados documentos como resultados por fornecedor e termo de homologação de processos licitatórios executados pelas instituições militares que elucidam os licitantes vencedores e as características dos materiais para os eventuais fornecimentos dos certames licitatórios. 
Na sequência, foram verificados dados do Sistema de Cadastramento Unificado de Fornecedores (SICAF), para fim de diagnosticar o perfil dos fornecedores que trabalham com produtos sustentáveis. Em seguida, os resultados foram analisados, agrupados por semelhança e sumarizados em quadros.

A análise e discussão dos resultados serão apresentadas a seguir.

\section{ANÁLISE E DISCUSSÃO DOS RESULTADOS}

Foram analisadas as licitações sustentáveis informadas em COMPRASNET (2013), qual possui uma área especifica para as contratações verdes do governo federal, denominada "Contratações Públicas Sustentáveis", conforme mostra a Figura 3.

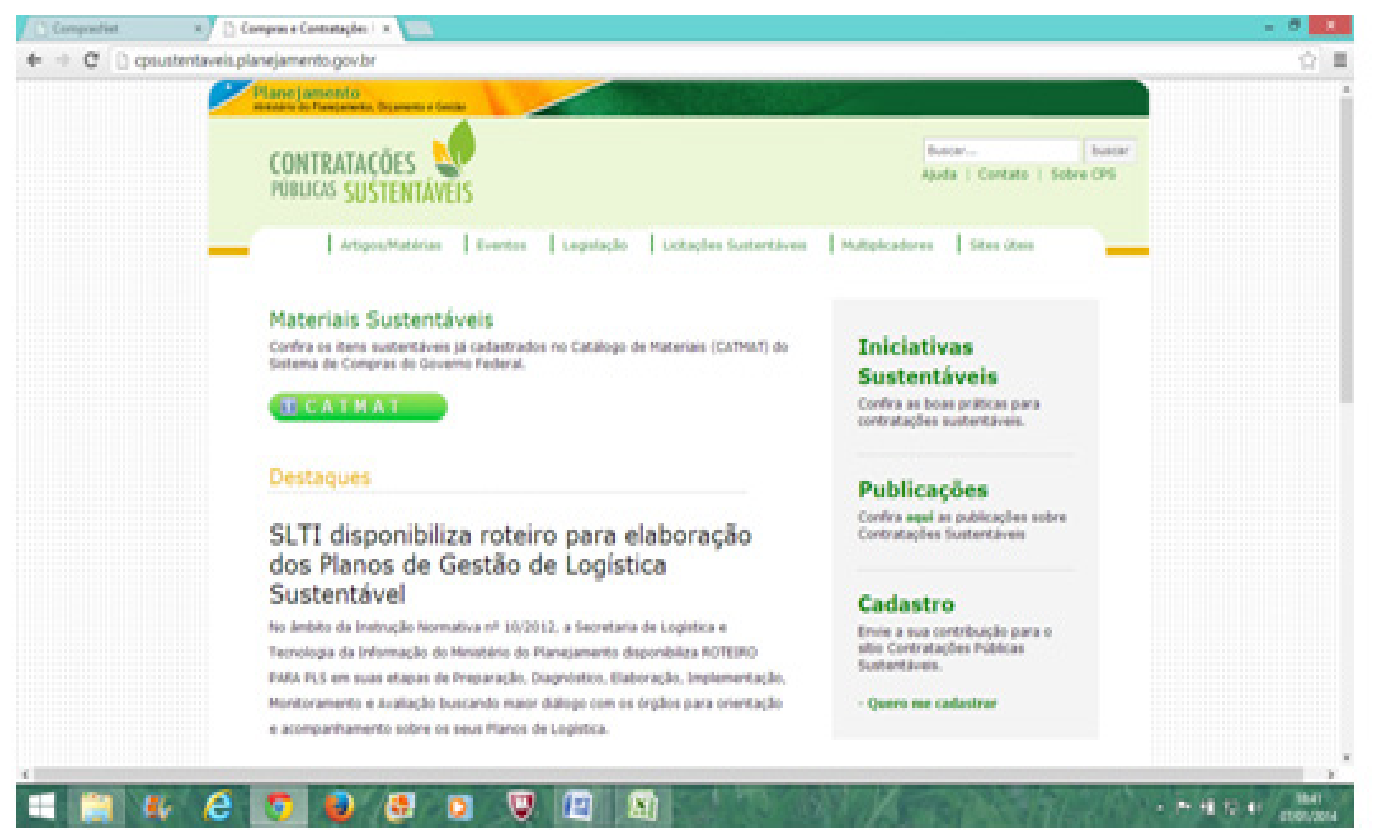

Figura 3. Página virtual - Contratações Públicas Sustentáveis

Fonte: Comprasnet, 2013.

Nesta área da página virtual do "Comprasnet", é disponibilizada uma relação de todas as licitações sustentáveis realizadas pelos órgãos integrantes do SIASG. De acordo com dados informados desta relação, foram realizados 197 processos licitatórios que continham algum critério sustentável pelas organizações militares do Exército, no período compreendido entre os anos de 2009 a 2011.

Entretanto, dentre os 197 processos licitatórios informados, somente 74 apresentam dados disponíveis para consulta de qualquer cidadão, num total de 159 itens sustentáveis licitados, na área de acesso livre, disponível no site "Comprasnet", configurando-se na base de dados desta pesquisa.

Dos processos licitatórios consultados, em sua totalidade foi adotada a modalidade de licitação pregão eletrônico. Sabe-se que a Lei $n^{\circ}$ 10.520/2002 (BRASIL, 2002) e o Decreto 5.450/2005 (BRASIL, 2005) tornam obrigatória a modalidade pregão para aquisição de bens e serviços comuns, sendo preferencialmente na forma eletrônica.

Meirelles (2010) define o sistema de registro de preço como um procedimento especial de licitação que se concretiza entre os interessados, num determinado período de tempo, para futuras contratações a serem realizadas pela administração, nas quantidades em conformidade com o instrumento convocatório. O sistema de registro de preços é um dispositivo que é amparado pela Lei de Licitações em seu art. 15, II, o qual descreve que sempre que possível as compras sejam processadas através deste mecanismo.

No caso de licitações sustentáveis, este registro formal de preços relativos à execução de serviços e no fornecimento de bens para uma eventual e futura contratação, permite à administração pública, a criação de depósitos enxutos, visto que a utilização dos insumos (bens e serviços) contratados, serão somente utilizados no momento de sua necessidade de aplicação, favorecendo, assim, economia de 
recursos financeiros em compras mais racionais e uma consequente redução na geração de resíduos sólidos.

Além disso, o pregão tem como principal característica a inversão de fases no procedimento de uma licitação, onde o julgamento das propostas antecedem a habilitação das licitantes (MAZZA, 2011), propiciando uma economia no tempo e de recursos ao poder público, tornando o processo licitatório mais ágil. O pregão na forma eletrônica utiliza meios eletrônicos, não exigindo à presença física dos licitantes no certame licitatório, permitindo uma maior competitividade, dando maior transparência à sessão pública, visto que os atos públicos ficam disponíveis a qualquer cidadão na internet. Sem mencionar, que a modalidade pregão eletrônico, confere uma economia de recursos naturais, seja em deslocamento de pessoas envolvidas no processo licitatório, seja no consumo materiais comuns a execução dos processos licitatórios, como papéis, canetas, lápis, copos plásticos, etc.

Verificou-se também, que no universo de licitações realizadas com critérios ambientais, somente uma delas apresentou $100 \%$ de itens sustentáveis. Nas demais licitações, a média de representatividade dos itens sustentáveis nas licitações praticadas foi de 3,16\% em relação aos itens não sustentáveis. Não foram realizadas no período de análise nenhuma licitação para a contratação de serviços, e sim somente para a aquisição de materiais.

Outro fator relevante foi à média de desconto dos itens sustentáveis nos certames licitatórios executados pelas entidades do Exército brasileiro. Constatou-se uma média de desconto entre o valor referenciado, ou seja, o valor máximo que a administração pública se propõe a pagar, com valor final arrematado pelos fornecedores na faixa de $54,3 \%$ do preço referenciado originalmente.

Destaca-se também que para constar na relação de licitação sustentável do Ministério do Planejamento, os editais de licitação não necessariamente tenham que constar somente itens com características sustentáveis, e sim se uma parte dos itens apresenta tais atributos sustentáveis, já se considera a licitação como um todo, como licitação sustentável.

Dos processos licitatórios analisados, constatou-se que 73 empresas foram vencedoras nos certames licitatórios, indicando assim um satisfatório número de empresas participantes nas licitações, haja vista que foram analisados 74 processos licitatórios, sendo disponíveis 159 itens sustentáveis. As características das empresas que participaram dos processos licitatórios das organizações militares fica elucidado no Quadro 8.

Quadro 8. Porte das empresas que participaram de licitações sustentáveis das organizações militares.

\begin{tabular}{|l|c|}
\hline \multicolumn{2}{|c|}{ Porte da empresa } \\
\hline Micro Empresa & $73,13 \%$ \\
\hline Pequeno Porte & $22,39 \%$ \\
\hline Outros & $4,48 \%$ \\
\hline
\end{tabular}

Fonte: COMPRASNET, 2013

Como mostra o Quadro 8, a predominância de participação das licitações sustentáveis realizadas pelas entidades do Exército brasileiro, foi de micro e pequenas empresas. Para que isso pudesse ter sido concretizado, vale ressaltar a lei que trata sobre o tratamento diferenciado despendido às micro e pequenas empresas nos processos licitatórios.

O Quadro 9 mostra como foi executada a Lei complementar $n^{\circ} 123$, de 14 de dezembro de 2006 (BRASIL, 2006), que trata sobre o tratamento diferenciado e favorecido a ser dispensado às microempresas (ME) e pequenas empresas (EPP) no âmbito dos Poderes da União, dos Estados, do Distrito Federal e dos Municípios.

Quadro 9. Tipo de tratamento nas licitações sustentáveis realizadas por organizações militares do Exército.

\begin{tabular}{|l|c|}
\hline \multicolumn{1}{|c|}{ Tipo de tratamento } & $\mathbf{\%}$ \\
\hline Tipo I - Participação Exclusiva de ME/EPP & 67,90 \\
\hline Nenhum tratamento diferenciado & 32,1 \\
\hline
\end{tabular}

Fonte: COMPRASNET, 2013. 
Conforme mostra o Quadro 9, grande parte das licitações sustentáveis utilizaram do benefício tipo I, que consiste em contratações destinadas exclusivamente para ME/EPP e Cooperativas. Este dispositivo é obrigatório quando valor da contratação de todos os itens de um edital de licitação não ultrapassa o valor R $\$ 80.000$ mil ou pode ser adotado quando uma "família" de itens similares de uma licitação não ultrapassa o valor de $\mathrm{R} \$ 80.000$. Isto justifica o grande percentual de ME/EPP nas licitações sustentáveis praticadas pelo Exército brasileiro. Também vale ponderar, que os itens com características sustentáveis, não apresentavam valores mais elevados que pudessem chamar a atenção das grandes empresas a participarem dos referidos certames licitatórios.

Outra constatação importante foi à média de idade de existência das empresas participantes das licitações sustentáveis, que ficou na faixa de 7,73 anos, indicando que são empresas com poucos anos de existência. Um dos motivos deve-se ao mecanismo de compra por licitação ainda ser incipiente no Brasil, haja vista que a Lei das Licitações e Contratos, surgiu em 1993, mas as modalidades mais usuais, como o pregão foi efetivado no âmbito dos Estados, Distrito Federal e Municípios, a partir da promulgação da lei específica, criando esta modalidade licitatória em 2002. Portanto, muitos fornecedores ainda não se adaptaram a esta nova realidade das compras governamentais, e novas empresas acharam nas licitações uma oportunidade de mercado.

O Exército está presente em todos os estados do Brasil, e isto reflete na distribuição da localidade das empresas que participaram das licitações sustentáveis, conforme o Quadro 10 mostra.

Quadro 10. Distribuição da localização das empresas que forneceram itens sustentáveis.

\begin{tabular}{|l|c|}
\hline \multicolumn{1}{|c|}{ UF } & \% de distribuição \\
\hline Piauí & 1,37 \\
\hline Acre & 1,37 \\
\hline Amapá & 1,37 \\
\hline Amazonas & 4,11 \\
\hline Bahia & 2,74 \\
\hline Ceará & 2,74 \\
\hline Distrito Federal & 2,74 \\
\hline Goiás & 4,11 \\
\hline Mato Grosso do Sul & 2,74 \\
\hline Minas Gerais & 6,85 \\
\hline Pará & 2,74 \\
\hline Paraíba & 1,37 \\
\hline Paraná & 24,66 \\
\hline Pernambuco & 2,74 \\
\hline Piauí & 1,37 \\
\hline Rio de Janeiro & 9,59 \\
\hline Rio Grande do Sul & 8,22 \\
\hline Santa Catarina & 2,74 \\
\hline São Paulo & 1,37 \\
\hline
\end{tabular}

Fonte: COMPRASNET, 2013.

Os estados com empresas que mais participaram são os estados do Paraná, Rio Grande do Sul e Rio de Janeiro. Um dos motivos para esta ocorrência se deve por estes estados compreenderem grandes áreas militares como Comando Militar do Sul e do Comando Militar do Leste, que concentram um grande número de organizações militares do Exército, viabilizando empresas destas regiões a participarem mais efetivamente das licitações, visto que fatores, como o frete, por exemplo, alteram substancialmente a formulação das propostas num certame licitatório.

Os produtos mais adquiridos nas licitações sustentáveis foram, em sua grande maioria, materiais de expediente rotineiros as seções administrativas e alguns eletrodomésticos. O Quadro 11 indica quais foram os itens sustentáveis adquiridos pelo Exército brasileiro. 
Quadro 11. Lista dos materiais sustentáveis licitados pelas organizações militares.

\begin{tabular}{|l|c|}
\hline \multicolumn{1}{|c|}{ Descrição do material } & $\%$ \\
\hline $\begin{array}{l}\text { Almofada carimbo, plástico reciclado, esponja absorvente revestida de tecido, azul, } \\
\text { entintada, 120 mm, 90 mm }\end{array}$ & 0,28 \\
\hline Aparelho ar condicionado & 1,67 \\
\hline Bateria recarregável, máquina fotográfica digital sony cyber-shot 8.1mp, lithium, 24 ah & 0,56 \\
\hline Cabeçote eletroduto, alumínio, 4 pol, para entrada de energia, manutenção & 0,56 \\
\hline $\begin{array}{l}\text { Cabo audiofrequência, 0,30 mm, 3, fio balanceado almax para microfone stéreo, } \\
\text { eletronica, cobre estanhado }\end{array}$ & 0,56 \\
\hline $\begin{array}{l}\text { Caixa embalagem, papelão reciclado, triplex, 600 mm, 500 mm, 400 mm, } \\
\text { m2, cola }\end{array}$ & 0,56 \\
\hline Cartão, papel reciclado, 240 g/m2, 16 cm, 10 cm & 0,28 \\
\hline Cartucho tinta impressora & 58,89 \\
\hline Cartucho toner impressora & 26,39 \\
\hline Classificador, papelão reciclado, 350 mm, 275 mm, 200 fl, ferragem metálica & 0,28 \\
\hline Envelope, papel reciclado & 2,50 \\
\hline Frigobar & 1,11 \\
\hline Impressora jato tinta/laser & 0,83 \\
\hline Microcomputador pessoal notebook & 0,56 \\
\hline Papel a4, papel reciclado/certificação fsc ou conselho de manejo florestal & 1,11 \\
\hline Papel pardo, celulose vegetal, reciclado & 1,39 \\
\hline Papel sulfite, papel sulfite reciclado & 2,50 \\
\hline
\end{tabular}

Fonte: COMPRASNET, 2013.

A característica principal sustentável dos itens licitados foi o fato de serem confeccionados com matéria reciclada (Quadro 11). Destacam-se os cartuchos e toners de impressoras, num total de 85,28 $\%$ dos itens sustentáveis adquiridos. Outros itens oriundos de matéria prima reciclada são as variedades de papéis, envelopes e caixas de papelão e demais itens de escritório.

Nos eletrodomésticos, a característica ambiental apresentada foi a presença de selos que atestam baixo consumo de energia. Os produtos com eficiência energética apresentam como característica principal a exigência do selo procel "A", atestando que os produtos cumprem as exigências de eficiência do INMETRO (Instituto Nacional de Metrologia, Qualidade e Tecnologia). Os itens listados com este atributo foram aparelhos de ar- condicionado e frigobar.

Os produtos de tecnologia da informação "verdes" encontrados foram microcomputadores do tipo notebooks, com descrição genérica, sendo pormenorizadas no Termo de Referência. Já as impressoras foram consideradas como itens sustentáveis aquelas que apresentam como características a impressão frente e verso.

Existe somente um tipo de item que exigiu a certificação de origem de procedência da matéria prima (o selo FSC que em português significa Conselho de Manejo Florestal), sendo este item o papel A4. E outros itens como o cabeçote de eletroduto e o cabo de áudio frequência não apresentaram características expressas em suas descrições para serem consideradas sustentáveis. 
Atualmente, existe um sistema de catálogos de materiais no site "Comprasnet", com 809 opções de itens sustentáveis que podem auxiliar os gestores na confecção de seus editais de licitação.

Pode-se perceber com base nos resultados por fornecedor e termo de homologação das licitações realizadas, que os fornecedores vencedores dos itens sustentáveis, também ganharam outros itens não sustentáveis. A justificativa para tal fato deve-se que os requisitos para considerarem os itens como "sustentável" serem pouco criteriosos ambientalmente.

Além do mais, por exemplo, eletrodomésticos com selo de baixo consumo de energia, ou impressoras com a peculiaridade de impressão frente e verso atualmente são bens usuais no mercado, sendo comercializadas no mercado não específico de produtos sustentáveis.

Assim, para ser realmente uma licitação sustentável, todas as etapas do processo licitatório devem conter critérios ambientais, do surgimento da necessidade de um eventual produto/serviço, até o recebimento e descarte correto dos eventuais resíduos gerados da contratação. A Figura 4 esquematiza as etapas a serem transcorridas na execução de uma licitação sustentável.

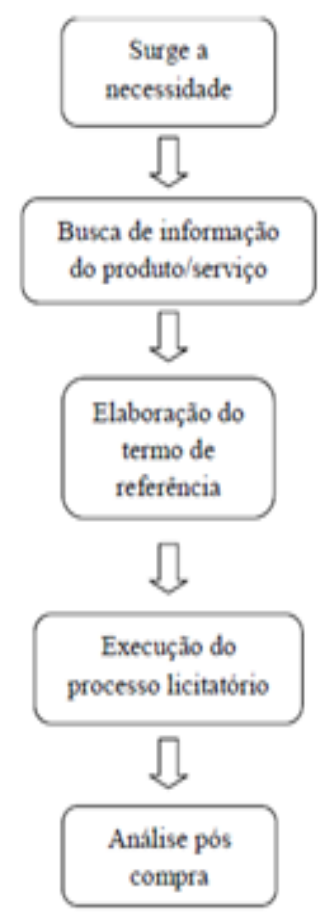

Figura 4. Fluxo de uma licitação sustentável

Fonte: Autor (2014)

A primeira etapa de uma licitação sustentável é o reconhecimento da necessidade. Nesta etapa se faz necessário uma análise criteriosa daquilo que se deseja realmente adquirir, para assim minimizar os impactos negativos na aquisição de produtos que venham a ser desnecessários.

Logo em seguida, tem-se a busca por informações mais detalhadas sobre os produtos e serviços a serem adquiridos. Nesta fase, se realiza a pesquisa de preços junto ao comércio local e verifica-se a viabilidade da contratação sustentável, sempre respeitando o critério da competitividade e economicidade.

Com as informações das etapas anteriores, elabora-se o termo de referencia, o qual conterá as especificações da eventual contratação sustentável, sempre respaldado pelos critérios da isonomia e ampla competitividade, onde melhor se elucida os critérios, entre eles os ambientais, que a administração pública busca em sua contratação.

Após o transcorrer das etapas anteriores, tem-se a escolha da modalidade licitatória adequada à característica do objeto e execução do certame licitatório. Por fim, é feita à análise pós compra, onde se verifica se os produtos/serviços contratados atenderam as expectativas e se levanta aspectos a se corrigir ou melhorar nas futuras licitações. 


\section{CONCLUSÃO}

As licitações sustentáveis realizadas pelo Exército brasileiro, e por outros órgãos da administração pública, ainda são incipientes no panorama das compras governamentais.

A modalidade de licitação utilizada para a execução das licitações foi o pregão eletrônico. Esta modalidade se enquadrou ao perfil do material adquirido e traz características no racionamento de insumos, utilização de mídias eletrônicas e conferiu maior agilidade na execução do processo licitatório na sua operação. Quando se trata de uma licitação sustentável, a maneira como se executa o processo também é importante.

No processo de licitação sustentável, todas as etapas do processo, do surgimento da necessidade até a efetivação e entrega do material ou execução do serviço contratado, os critérios de sustentabilidade ambiental devem estar contidos em todas as etapas.

Quanto ao perfil das empresas que saíram vencedoras nos processos licitatórios, não são empresas que trabalham unicamente com produtos sustentáveis, pois os itens licitados apresentavam características ambientais, com atributos não muito exigentes, onde muitos destas características estão se tornando inerentes aos produtos no mercado convencional, não favorecendo empresas que trabalham unicamente no ramo de produtos verdes.

Os produtos que foram considerados sustentáveis, muitas vezes se confundiram com os não sustentáveis nas suas características nos editais de licitação. Não foram mencionados na descrição dos itens licitados, as características das embalagens a qual acondicionaram estes produtos, fator este importante, pois entre um dos objetivos de uma licitação sustentável é a diminuição da geração de resíduos sólidos.

Além disso, os valores ofertados estavam abaixo do valor referenciado, onde se pressupunha que produtos sustentáveis no mercado convencional, geralmente, apresentariam valores de mercado acima dos produtos similares.

Portanto, a promoção dos critérios ambientais nas licitações sustentáveis realizadas pelo Exército, ainda é incipiente, no que tange a variedade de itens licitados e de significância no cenário das licitações praticadas.

Enfim, o Estado fomentando boas práticas ambientais em suas compras governamentais, age como indutor de mudanças tanto na esfera econômica, com o estímulo de setores envolvidos com a fabricação e comercialização de produtos ambientalmente corretos, bem como garantindo direitos constitucionais a população na preservação de um ambiente equilibrado para esta e para as futuras gerações.

\section{REFERÊNCIAS}

AKATU. Pesquisa Akatu 2012, Rumo a Sociedade do Bem-Estar: Assimilação e Perspectivas do Consumo Consciente no Brasil - Percepção da Responsabilidade Social empresarial pelo Consumidor Brasileiro. São Paulo: Instituto Akatu, 2013. 96p.

ALEXANDRINO, M.; PAULO, V. Direito administrativo descomplicado. 19. ed. Rio de Janeiro: Forense; São Paulo: Método, 2011.

BARBIERI, J. C. Responsabilidade social empresarial e empresa sustentável: da teoria à prática. 2. ed. atual. e ampl. São Paulo: Saraiva, 2012.

BELLEN, H. M.V. Indicadores de Sustentabilidade: uma análise comparativa, Rio de Janeiro: FGV, 2005. $256 \mathrm{p}$.

BETIOL, L. S. et al. Compra Sustentável: a força do consumo público e empresarial para uma economia verde e inclusiva. São Paulo: Programa Gestão Pública e Cidadania, 2012. 144p.

BINDERMAN, R. et al,(Orgs). Guia de Compras públicas sustentáveis. Uso do poder de compra do governo para a promoção do desenvolvimento sustentável. 2. ed. Rio de Janeiro: FGV, 2008. 
BRASIL. Ministério do Planejamento, Orçamento e Gestão. Informações Gerenciais de Contratações Públicas Sustentáveis, janeiro a dezembro de 2012. [2014a]. Disponível em: <http://www.comprasnet.gov.br/ ajuda/Manuais/03-01_A_12_INFORMATIVO\%20COMPRASNET_ComprasSustentaveis.pdf $>$. Acesso em: 5 jan 2014.

BRASIL. Ministério do Planejamento, Orçamento e Gestão. Informações Gerenciais de Contratações Públicas Sustentáveis, janeiro a julho de 2013. [2014b]. Disponível em: <http://www.comprasnet.gov.br/ajuda/ Estatisticas/2013/01_A_10_INFORMATIVO_COMPRASNET_Compras_Sustentaveis_2013.pdf >. Acesso em: 07 fev. 2014.

BRASIL. Ministério Do Planejamento, Orçamento e Gestão. Guia de Compras Públicas Sustentáveis para Administração Federal. [2013a]. Disponível em: <http://cpsustentaveis.planejamento.gov.br/wp-content/ uploads/2010/06/Cartilha.pdf>. Acesso em: 5 set 2013.

BRASIL. Ministério do Meio Ambiente. Agenda Ambiental na Administração Pública/Eixo temático/Licitação Sustentável/Legislações. 2013b. Disponível em http://www.mma.gov.br/responsabilidade-socioambiental/a3p/eixos-tematicos/item/9028>. Acesso em de 04 nov 2013.

BRASIL. Ministério do Planejamento, Orçamento e Gestão. Contratações Públicas Sustentáveis, legislação. 2013c. Disponível em: <http://cpsustentaveis.planejamento.gov.br/?page_id=9>. Acesso em: 15 out 2013.

BRASIL. Decreto $n^{0}$ 7.946, de 7 de março de 2013 - Dispõe sobre os efetivos do pessoal militar do Exército, em serviço ativo, para 2013. Diário Oficial [da] República Federativa do Brasil, Brasília, DF. 2013d. Disponível em: < http://www.planalto.gov.br/ccivil 03/ Ato2011-2014/2013/Decreto/D7946.htm\#art5>. Acesso em: $20 \mathrm{dez} 2013$.

BRASIL. Ministério do Planejamento, Orçamento e Gestão. Comprasnet, o portal de compras do governo federal. 2013e. Disponível em <http://www.comprasnet.gov.br/>. Acesso em: 15 out 2013.

BRASIL. Lei 12.651 de 25 de maio de 2012. Institui o Novo Código Florestal Federal. 2012. Disponível em: <http://www.planalto.gov.br/ccivil_03/_ato2011-2014/2012/lei/112651.htm>. Acesso em 06 fev. 2014.

BRASIL. Ministério do Planejamento, Orçamento e Gestão. Secretária de Estado da Administração e do Patrimônio. Instrução Normativa n ${ }^{\circ}$ 01, de 19 de janeiro de 2010. Diário Oficial [da] República Federativa do Brasil, Brasília, DF. 2010a. Disponível em: <http://cpsustentaveis.planejamento.gov.br/wp-ontent/uploads/2010/03/Instru\%C3\%A7\%C3\%A3o-Normativa-01-10.pdf. >. Acesso em: 30 ago 2013.

BRASIL. Tribunal de Contas da União. Licitações e contratos: orientações e jurisprudência do TCU/ Tribunal de Contas da União. 4. ed. rev. e aum. Brasília, 2010b. 910p. Disponível em: < http://portal2.tcu.gov.br/ portal/pls/portal/docs/2057620.PDF>. Acesso em: 30 ago 2013.

BRASIL. Lei ${ }^{\circ} 12.349$, de 15 de dezembro de 2010. Altera as Leis nos 8.666, de 21 de junho de 1993, 8.958, de 20 de dezembro de 1994, e 10.973, de 2 de dezembro de 2004; e revoga o $§ 1$ o do art. 2o da Lei no 11.273, de 6 de fevereiro de 2006. Diário Oficial [da] República Federativa do Brasil, Brasília, DF. 2010c. Disponível em: <http://www.planalto.gov.br/ccivil_03/_Ato2007-2010/2010/Lei/L12349.htm.> Acesso em 10 jan 2014.

BRASIL. Ministério do Meio Ambiente. Agenda Ambiental na Administração Pública. 6 ed. rev e atual. Brasília. 2009. 95p. Disponível em <http://www.mma.gov.br/estruturas/a3p/ arquivos/cartilha a3p 36.pdf $>$. Acesso em 17 de jul 2013.

BRASIL. Lei Complementar $n^{\circ} 123$, de 14 de Dezembro de 2006. Institui o Estatuto Nacional da Microempresa e da Empresa de Pequeno Porte; altera dispositivos das Leis n ${ }^{\circ} 8.212$ e 8.213, ambas de 24 de julho de 1991, da Consolidação das Leis do Trabalho - CLT, aprovada pelo Decreto-Lei n ${ }^{\circ} 5.452$, de $1^{\circ}$ de maio de 
1943, da Lei $\mathrm{n}^{\circ}$ 10.189, de 14 de fevereiro de 2001, da Lei Complementar $\mathrm{n}^{\circ}$ 63, de 11 de janeiro de 1990; e revoga as Leis $n^{\circ}$ 9.317, de 5 de dezembro de 1996, e 9.841, de 5 de outubro de 1999. Diário Oficial [da] República Federativa do Brasil, Brasília, DF. 2006. Disponível em: <http://www.receita.fazenda.gov.br/ Legislacao/LeisComplementares/2006/leicp123.htm>. Acesso em 2 jan 2014.

BRASIL. Decreto ${ }^{\circ} 5.450$, de 31 de maio de 2005.

Regulamenta o pregão, na forma eletrônica, para aquisição de bens e serviços comuns, e dá outras providências. Diário Oficial [da] República Federativa do Brasil, Brasília, DF. 2005. Disponível em: < http://www. planalto.gov.br/ccivil_03/_ato2004-2006/2005/decreto/d5450.htm>. Acesso em: 10 nov 2013.

BRASIL. Lei n ${ }^{\circ} 10.520$, de 17 de julho de 2002. Institui, no âmbito da União, Estados, Distrito Federal e Municípios, nos termos do art. 37, inciso XXI, da Constituição Federal, modalidade de licitação denominada pregão, para aquisição de bens e serviços comuns, e dá outras providências. Diário Oficial [da] República Federativa do Brasil, Brasília, DF. 2002. Disponível em: < http://www.planalto.gov.br/ccivil 03/leis/2002/

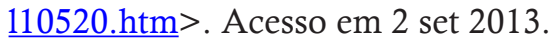

BRASIL. Lei n 9.795, de 27 de abril de 1999. Dispõe sobre a educação ambiental, institui a Política Nacional de Educação Ambiental e dá outras providências. Diário Oficial [da] República Federativa do Brasil, Brasília, DF. 1999. Disponível em http://www.planalto.gov.br/ccivil 03/leis/19795.htm>. Acesso em: 30 ago 2013.

BRASIL. Lei n 8.666, de 21 de junho de 1993. Regulamenta o art. 37, inciso XXI, da Constituição Federal, institui normas para licitações e contratos da Administração Pública e dá outras providências. Diário Oficial [da] República Federativa do Brasil, Brasília, DF. 1993. Disponível em <http://www.planalto.gov.br/ccivil 03/leis/18666cons.htm>. Acesso em: 30 ago 2013.

BRASIL. Constituição da República Federativa do Brasil de 1988. DF. 1988. Disponível em: < http://www. planalto.gov.br/ccivil_03/constituicao/constituicao.htm>. Acesso em 17 jul. 2013.

BRASIL. Lei n ${ }^{\circ}$ 6.938, de 31 de agosto de 1981. Dispõe sobre a Política Nacional do Meio Ambiente, seus fins e mecanismos de formulação e aplicação, e dá outras providências. Diário Oficial [da] República Federativa do Brasil, Brasília, DF. 1981. Disponível em: < http://www.planalto.gov.br/ccivil 03/leis/16938.htm>. Acesso em: 25 ago 2013.

BRASIL. Lei no 4.771 , de 15 de setembro de 1965. Institui o novo Código Florestal brasileiro. Diário Oficial [da] República Federativa do Brasil, Brasília, DF. 1965. Disponível em: <http://www.mma.gov.br/port/ conama/legiabre.cfm?codlegi=311>.. Acesso em: 25 ago 2013.

DIAS, R. Marketing Ambiental: ética, responsabilidade social e competitividade nos negócios. São Paulo: Atlas, 2012. 216p.

DI PIETRO, M, S, Z. Direito Administrativo. 25. ed. São Paulo: Atlas, 2012. 932p.

GLOBAL FOOTPRINT NETWORK. 2011 Annual Report. Disponível em $<\underline{\text { http://www.footprintne- }}$ twork.org/en/index.php/GFN/page/annual report 2011/>. Acesso em 23 ago 2013.

IBOPE. Instituto Brasileiro de Opinião Pública e Estatística. ICS Índice de Confiança Social 2013. Disponível em: <http://www.ibope.com.br/pt-br/noticias/paginas/cai-a-confianca-dos-brasileiros-nas-instituicoes-. aspx>. Acesso em 05 jan 2014. 